\title{
A study of the genetic polymorphism of Plasmopara viticola in the vineyards of the Krasnodar Territory
}

Makarkina M.V., Tokmakov S.V., Ilnitskaya E.T.

Federal State Budget Scientific Institution "North Caucasian Federal Scientific Center of Horticulture, Viticulture, Wine-making", Krasnodar, Russia

E-mail: konec_citatu@mail.ru

\begin{abstract}
Key message. The genetic diversity of the pathogen downy mildew (Plasmopara viticola) in the vineyards of the Krasnodar Territory was studied. It was shown that populations of $P$. viticola are variable on different varieties and at different geographical points.
\end{abstract}

Keywords: grapes, downy mildew, Plasmopara viticola, DNA markers, genetic diversity

Downy mildew is one of the most harmful diseases of grapes, caused by the oomycete Plasmopara viticola (Berk. et Curt.) Berl. et de Toni. The relevance of studying the biodiversity of $P$. viticola in different zones of viticulture is determined not only by fundamental goals, but also by the practical importance of such works to better understand the epidemiological cycle of $P$. viticola and to clarify disease prediction models. The aim of the work is to study the genetic diversity of $P$. viticola in the vineyards of the Krasnodar Territory on grape varieties with different levels of resistance to downy mildew. The study was carried out on pathogen samples collected on various grape varieties that are resistant to downy mildew (Augustine, Kishmish 342, Bianca, Kunleany, Vanessa Sidless) and unstable genotypes (Kishmish luchistyi, Kishmish belyi kruglii, Kishmish rozovyi, Attica, Merlot noir, Cabernet Sauvignon) affected by downy mildew in the active phase. The collection of material was carried out in May-August 2019 at various points in the Krasnodar Territory. 48 samples of P. viticola DNA were analyzed (three samples from each cultivar/geographical point). DNA was isolated using the CytoSorb kit (Synthol, Russia). We used DNA markers BER, ISA, CES, GOB, PV91, PV137, PV143, PV144, recommended for studying the genetic diversity of $P$. viticola. The work was performed by PCR. Using the GOB DNA marker, 37 alleles of different sizes were identified, PV144 - 20, CES - 10, BER - 3, PV91 - 3, PV137 - 2, ISA - 1, PV143 - 1. ISA and PV143 markers did not reveal polymorphism in the studied sampling. According to the results of this work, it was shown that populations of $P$. viticola are variable on different varieties and at different geographical points. The study of $P$. viticola samples parasitizing on varieties with different degrees of resistance to downy mildew growing in the same and at different geographical points did not reveal any regularities. The work continues, it is planned to expand the sample of the examined grape varieties, as well as to attract additional markers used in the study of $P$. viticola to get a clearer picture of the genetic structure of the pathogen populations. This study was conducted in the Krasnodar Territory for the first time.

The reported study was funded by RFBR and the Administration of Krasnodar Region, according to the research project № 19-416-233038 r_mol_a.

\section{Исследование генетической полиморфности Plasmopara viticola на виноградниках Краснодарского края} Макаркина М.В., Токмаков С.В., Ильницкая Е.T.

Федеральное государственное бюджетное научное учреждение «Северо-Кавказский федеральный научный центр садоводства, виноградарства, виноделия, Краснодар, Россия

Аннотация. Изучено генетическое разнообразие возбудителя милдью (Plasmoраra viticola) на виноградниках Краснодарского края. Показано, что популяции Р. viticola вариабельны на разных сортах и в разных географических точках.

Ключевые слова: виноград, милдью, Plasmopara viticola, ДНК-маркеры, генетическое разнообразие

Милдью одно из наиболее вредоносных заболеваний винограда, возбудителем которого является оомицет Plasmopara viticola (Berk. et Curt.) Berl. et de Toni. Актуальность изучения биоразнообразия P. viticola в различных зонах виноградарства определяется не только фундаментальными целями, но и практическим значением подобных работ для лучшего понимания эпидемиологического цикла P. viticola и для уточнения моделей прогнозирования заболевания. Цель работы - изучить генетическое разнообразие $P$. viticola на виноградниках Краснодарского края на сортах винограда с различным уровнем устойчивости к милдью. Исследование проведено на образцах патогена, собранных на различных сортах винограда, обладающих устойчивостью к милдью (Августин, Кишмиш 342, Бианка, Кунлеань, Ванесса Сидлесс) и неустойчивых генотипах (Кишмиш лучистый, Кишмиш белый круглый, Кишмиш розовый, Аттика, Мерло, Каберне-Совиньон) пораженных милдью в активной фазе. Сбор материала проведён в мае-августе 2019 г. в различных точках Краснодарского края. Проанализировано 48 образцов ДНК P. viticola (по три образца с каждого сорта/географической точки). ДНК выделена набором ЦитоСорб (Синтол, Россия). Использовали ДНК-маркеры BER, ISA, CES, GOB, PV91, PV137, PV143, PV144, рекомендованные для изучения генетического разнообразия P. viticola. Работа выполнена методом ПЦР. С помощью ДНКмаркера GOB удалось выявить 37 аллелей разного размера, PV144 - 20, CES - 10, BER - 3, PV91 - 3, PV137 - 2, ISA - 1, PV143 - 1. Маркеры ISA и PV143 не выявили полиморфизма в исследуемой выборке. По результатам проведенной работы показано, что популяции $P$. viticola вариабельны на разных сортах и в разных географических точках. Изучение образцов $P$. viticola, паразитирующих на сортах с различной степенью устойчивости к милдью, произрастающих в одной и в разных географических точках не выявило каких-либо закономерностей. Работа продолжается, планируется расширить выборку обследуемых сортов винограда, а также привлечь дополнительные маркеры, используемые в изучении P. viticola, чтобы получить более ясную картину генетической структуры популяций патогена. Данное исследование в Краснодарском крае проведено впервые.

Работа выполнена при финансовой поддержке РФФИ и Администрации Краснодарского края в рамках научного проекта № 19-416-233038 р_мол_а. 